University of Nebraska - Lincoln

DigitalCommons@University of Nebraska - Lincoln

Faculty Publications from the Harold W. Manter Laboratory of Parasitology

8-1993

Extending the Symbiotype Concept to Host Voucher Specimens

Daniel R. Brooks

University of Toronto,dnlbrooks@gmail.com

Follow this and additional works at: https://digitalcommons.unl.edu/parasitologyfacpubs

Part of the Parasitology Commons

Brooks, Daniel R., "Extending the Symbiotype Concept to Host Voucher Specimens" (1993). Faculty Publications from the Harold W. Manter Laboratory of Parasitology. 204.

https://digitalcommons.unl.edu/parasitologyfacpubs/204

This Article is brought to you for free and open access by the Parasitology, Harold W. Manter Laboratory of at DigitalCommons@University of Nebraska - Lincoln. It has been accepted for inclusion in Faculty Publications from the Harold W. Manter Laboratory of Parasitology by an authorized administrator of DigitalCommons@University of Nebraska - Lincoln. 


\section{Extending the Symbiotype Concept to Host Voucher Specimens}

Recently, Frey et al. (1992) suggested that parasitologists deposit specimens of hosts from which type specimens of new parasite species are collected. Their proposal was directed especially at systematic and evolutionary biologists. Frey et al. (1992) pointed out that, whether one emphasizes microevolutionary (e.g., Price, 1980) or macroevolutionary (e.g., Brooks and McLennan, 1993) aspects of parasite evolutionary biology, much of the context of evolution involves hosts. Robust estimates of the selective effects and the patterns of diversification of host associations require the best possible estimates of the host species involved. This is true for discussions of the relative importance of host specificity in parasite evolution, of host switching in parasite speciation, studies of the patterns and processes of parasite-host coevolution, and differentiation of evolutionary and ecological components of community evolution (Brooks and McLennan, 1993). I support the proposal by Frey et al. (1992) and suggest an extension of it: that parasitologists deposit voucher specimens of all host species examined in the course of survey or inventory studies, including purely ecological field studies. This practice would enhance and broaden the goals of the Frey et al. proposal and could produce new opportunities for parasitologists in biodiversity and conservation studies.

The parasitological literature is replete with surveys reporting parasite species inhabiting particular host species in particular geographic locations. By the early 1970 s, increasing numbers of parasitologists had become interested in trying to synthesize the results of all those survey reports. It quickly became apparent that this synthesis would not be possible because relatively few reports were documented by deposited specimens of the parasite species reported, and thus species identities could not be confirmed. A classic example is the confusion surrounding the identity of the allocreadiid digeneans reported as Crepidostomum cornutum and Crepidostomum cooperi inhabiting North American freshwater fishes (see Caira [1989] for a synopsis). Consequently, major parasitological journals adopted a policy that, just as descriptions of new species required that type specimens be deposited, survey reports of previously described species required voucher specimens be deposited in a museum collection. Some museum collections, most notably the Harold W. Manter Laboratory under the direction of M. H. Pritchard, have even advertised their willingness to receive such voucher specimens, making it easier for parasitologists to establish new habits with respect to documenting their work.

My suggestion is not based solely on systematic and evolutionary considerations. I believe that parasitologists can and should make their presence felt more strongly in biodiversity inventories and in biodiversity policy-making decisions. Parasitological information can be of value to biodiversity considerations in 3 ways. First, parasites are symbols of trophic interactions and connections among different species within an ecosystem, and thus immense amounts can be learned about a given biota by knowing the parasites that reside within it. Second, parasites can be causal agents of zoonoses, and thus parasitologists can provide information about the potential biohazards to and from imported and native species. This is becoming more important as more habitat is disturbed and more species are moved around the world. Third, parasitic diseases of humans and of their domesticated animals and plants represent a direct link between the purely biological aspects of biodiversity and conservation issues and the more pragmatic necessity for sustainable development in underdeveloped countries. Parasitologists are usually well aware of this, but we have not, in general, made nonparasitologists aware that we have special information that could be useful in a larger biological and socioeconomic arena.

To be involved in such efforts, parasitologists must strive to create and maintain data bases that can be useful both to policy makers and to investigators pursuing the increasingly important and difficult task of documenting, managing, and conserving biodiversity. As appreciation grows for the significant role that parasites play in affecting the behavior, population dynamics, and community structure of hosts, so should appreciation grow for the special knowledge parasitologists possess. For example, the baseline data, such as the ecological information about host and site of infection within the host, that accompany each deposited specimen of a parasite species are often more extensive than those accompanying deposited specimens of nonparasitic species. For example, how often does a deposited specimen of a vertebrate include information about the parasites that inhabited it? With the establishment and growth of such data bases, the employment opportunities for parasitologists should also grow, and with increased awareness of the importance of parasitologists trained in areas relevant to biodiversity (systematics, evolution, ecology, behavior, and genetics) should come increased funding opportunities for training programs. If parasitologists become recognized as those people most likely to acquire broadbased biodiversity information and to make it available through depositions in traditional and preserved tissue museum collections, their standing within the biological community in general will improve accordingly.

Implementing this proposal will require additional preparation and work on the part of parasitologists. Parasitologists will have to make certain they understand how to preserve host specimens, or parts of host specimens, in a manner suitable for study by nonparasitologists (I believe many parasitologists already know this) and will have to carry the materials necessary for preserving host specimens into the field. But this should not deter efforts, because the potential benefits for parasitology far outweigh the possible inconveniences. For example, because parasitologists often dissect hosts or take blood samples to collect parasites, they can collect host material suitable for molecular analysis as well as traditional museum specimens. Thus, they can provide 
host voucher specimens in a variety of forms, ranging from whole specimens to tissues frozen or preserved in alcohol. In this manner, parasitologists can tailor their host contributions according to the space limitations and research interests of particular museum collections. One positive response to this proposal is for parasitologists to form research teams with nonparasitologists working on host groups. My studies on the helminth fauna of neotropical freshwater stingrays began as part of a larger study of the overall biology of the rays themselves that included vertebrate morphologists, developmental biologists, and comparative physiologists.

I offer a practical example in closing. There is currently much concern about the status of frog species worldwide. Given the number of published surveys of parasites from frogs worldwide, and the number of introductory biology laboratory exercises that have used frogs to show parasites to students, it seems reasonable that parasitologists have something important to contribute to discussions about the future survival of frogs. Unfortunately, the data base for frog parasites is tied to greatly outdated host taxonomy. Consider the ranid frogs belonging to a group called leopard frogs or grass frogs in North and Central America. For many years, herpetologists believed that a single species, Rana pipiens, ranged from near the Arctic Circle to Panama. This "species" of frog hosted an amazing diversity of parasite species, often including multiple congeners. The picture that emerged was of a widespread and incredibly successful generalist host that acquired local parasites throughout its range or that was so widely dispersed that its parasite fauna exhibited greater evolutionary diversification than the host (e.g., multiple species of Haematoloechus, Goroderina, Glypthelmins, and Cephalogonimus).

Beginning with the landmark study by Pace (1974) and continuing today (see review by Hillis [1988]), herpetologists are recognizing that leopard frogs represent a clade of 27 or more extant and recently extinct species. Parasitology has lagged. The Index-Catalogue of Medical and Veterinary Zoology, which ceased publication in 1982 after reporting literature records up to 1981 , listed host names according to identifications by authors of the publications. The Index-Catalogue of Medical and Veterinary Zoology records for digeneans inhabiting species in the $R$. pipiens clade all use $R$. pipiens as the host, with the exception of those by Caballero y Caballero (1941, 1942) and Brooks (1976, 1979); all studies of nematode and protist parasites use $R$. pipiens as the host name. With the exception of the Brooks studies, no host specimen is known to have been deposited in museum collections. Those 2 studies thus represent the only confirmed records of parasites from particular species of leopard frogs, including $R$. pipiens sensu stricto. Consequently, there is no way to ascertain the specific identity of the hosts reported in other surveys, except by matching today's geographic distributions of those species with published parasite survey results of as many as $60 \mathrm{yr}$ ago. Even this crude method, however, reveals 2 salient points for parasitologists.

First, after nearly a century of parasite studies on leopard frogs, most species of leopard frogs have not had parasites reported from them, including some that have become extinct recently. In addition, many re- cords of "Rana pipiens" are from geographic areas in which more than 1 species of leopard frogs exists, leaving open the possibility that some reported host identifications are incorrect. Consequently, there is a lot of basic survey work still to be done on a group of hosts that were thought to have been among the most extensively studied in North America.

Second, there are apparent host and geographic distribution patterns associated with the digenean fauna of leopard frogs. It is therefore possible that some evolutionary components to explain the origins and diversification of the digenean (and other parasite) fauna of these frogs will be found once more host species have been sampled. Such information can be used to augment current understanding about the evolution and ecology of this group of frogs. For example, Lynch (1978) used parasite information supplied by Brooks (1976) in a herpetological study of microhabitat differentiation between $R$. pipiens and Rana blairi in $\mathrm{Ne}-$ braska, where the 2 species share some points of sympatry. Thus, there is a need for parasitologists to provide comparative data about the parasite fauna of leopard frogs, and by extension, a need to train systematic parasitologists using modern methods of phylogenetic analysis, comparative biology, behavioral ecology, and historical ecology.

\section{LITERATURE CITED}

Brooks, D. R. 1976. Parasites of amphibians of the Great Plains, II. Platyhelminths of amphibians in Nebraska. Bulletin of the University of Nebraska State Museum 10: 65-92.

1979. New records for amphibian and reptilian trematodes. Proceedings of the Helminthological Society of Washington 46: 286-289.

$\longrightarrow$, AND D. A. McLennan. 1993. Parascript: Parasites and the language of evolution. Smithsonian Institution University Press, Washington, D.C., $429 \mathrm{p}$.

Caballero y Caballero, E. 1941. Trematodos de las ranas de la cienaga de Lerma, Mexico. I. Annales del Instituto de Biologia, Universidad $\mathrm{Na}$ cional de Mexico 12: 623-641.

- 1942. Trematodos de las ranas de la cienaga de Lerma, Mexico. III. Redescripcion de una forma norteamericana de Haematoloechus y algunos consideraciones sobre Glypthelmins californiensis (Cort, 1919). Annales del Instituto de Biologia, Universidad Nacional de Mexico 13: 71-79.

CaIRA, J. N. 1989. A revision of the North American papillose Allocreadiidae with independent cladistic analyses of larval and adult forms. Bulletin of the University of Nebraska State Museum 11: 158.

Frey, J. K., T. L. Yates, D. W. Duszynski, W. L. GANNON, AND S. L. Gardner. 1992. Designation and curatorial management of type host specimens (symbiotypes) for new parasite species. Journal of Parasitology 78: 930-932.

Hillis, D. M. 1988. Systematics of the Rana pipiens complex: Puzzle and paradigm. Annual Review of Ecology and Systematics 19: 39-63.

LYNCH, J. D. 1978. The distribution of leopard frogs (Rana blairi and Rana pipiens) (Amphibia, Anura, 
Ranidae) in Nebraska. Journal of Herpetology 12: 157-162.

PACE, A. E. 1974. Systematic and biological studies of the leopard frogs (Rana pipiens complex) of the United States. Miscellaneous Publications of the Museum of Zoology, University of Michigan 184: $1-140$.
Price, P. W. 1980. The evolutionary biology of parasites. Princeton University Press, Princeton, New Jersey, 237 p.

Daniel R. Brooks, Department of Zoology, University of Toronto, Toronto, Ontario, Canada M5S 1 A1. 